\title{
Clinical, Histopathological and Mineralogical Analysis Findings of an Unusual Case of Pneumoconiosis
}

\section{Sıradışı Bir Pnömokonyozis Olgusunun Klinik, Histopatolojik ve Mineralojik Analiz Bulguları}

\author{
Mehmet KEFELi' ${ }^{1}$, ilkser AKPOLAT ${ }^{1}$, Handan ZEREN ${ }^{3}$, Atilla Güven ATICI ${ }^{2}$, Pascal DUMORTIER ${ }^{4}$, \\ Koichi HONMA ${ }^{5}$, Bilge CAN' \\ Departments of ${ }^{1}$ Pathology and ${ }^{2}$ Chest Diseases, Ondokuz Mayıs University, Faculty of Medicine, SAMSUN, TURKEY \\ ${ }^{3}$ Department of Pathology, Çukurova University, Faculty of Medicine, ADANA, TURKEY \\ ${ }^{4}$ Department of Chest, Université Libre de Bruxelles, Erasme Hospital, Laboratory of Mineralogy, BRUSSELS, BELGIUM, \\ ${ }^{5}$ Department of Pathology, Dokkyo Medical School, TOKYO, JAPAN
}

\begin{abstract}
A 43-year-old man with a long history of dyspnea which had progressively worsened over the preceding month is presented.

He had worked in an antimony mine for 3 years. Radiologically, there were diffuse reticulonodular shadowing opacities in both lung parenchymas. Histopathologic examination of the open-lung biopsy specimen revealed alveolar spaces filled with dust-laden macrophages and amorphous proteinaceous semifluid, the latter being immunoreactive for Human Surfactant Apoprotein A, associated with marked interstitial accumulation of the similar-looking macrophages along the bronchovascular bundles and mild interstitial fibrosis. Silicotic nodules or mixed dust fibrosis were not seen. The patient was diagnosed as silicoproteinosis with unusual histopathological features because he had worked in an antimony mine for only 3 years and had $86 \%$ silica in a mineralogical analysis.
\end{abstract}

Pneumoconiosis is a rare lung disease which may be confused with other interstitial lung diseases. Clinical, radiological and unusual histopathologic features of this rare case are presented and discussed with the differential diagnosis, especially of mixed dust pneumoconiosis.

Key Words: Pneumoconiosis, Silicosis, Dust, Antimony

\section{ÖZ}

Uzun zamandır devam eden ve son aylarda şiddetlenen dispne yakınması bulunan 43 yaşında erkek hasta sunulmaktadır.

Hasta üç yıldır antimon madeninde çalışmaktaydı. Radyolojik olarak her iki akciğer parankiminde diffüz retikülonodüler opasiteler mevcuttu. Açık akciğer biyopsisinin histopatolojik incelemesinde alveolar boşlukların içerisinde pigment içeren makrofajlar ve Human Surfactant Apoprotein A ile immünreaktif amorf proteinöz materyal birikimi izlendi. Beraberinde bronkovasküler bandlar boyunca aynı nitelikteki makrofajların belirgin infiltrasyonu ve hafif derecede interstisyel fibrozis de mevcuttu. Ancak silikotik nodül veya mikst "dust" fibrozisi izlenmedi. Olgunun üç yıldır antimon madeninde çalışıyor olması ve doku mineralojik analizinde \%86 oranında silika da saptanması nedeniyle olguya sıra dıșı histopatolojik özellikleri olan silikoproteinozis tanısı konuldu.

Diğer interstisyel akciğer hastalıkları ile karışabilen pnömokonyoz, nadir bir akciğer hastalığıdır. Bu nadir olgunun klinik, radyolojik ve sıra dışı histopatolojik özellikleri sunulmakta ve özellikle mikst "dust" pnömokonyoz olmak üzere ayırıcı tanısı tartışılmaktadır.

Anahtar Sözcükler: Pnömokonyoz, Silikoz, Tozlar, Antimon

\section{INTRODUCTION}

Pneumoconiosis is defined as a non-neoplastic lung reaction to inhalation of mineral or organic dusts encountered in the workplace or environment. The majority of reactions are chronic, due to exposure to dust over a period of many years and having latencies often exceeding several decades. Acute reactions are usually the result of industrial accidents where exposures are relatively brief but at extremely high levels (1-4). Lung fibrosis may have many causes and also

(Turk Patoloji Derg 2012, 28:184-188)

Received : 17.01.2011 Accepted : 27.01.2011 may be host-dependent. Pneumoconiosis is one of the causes of lung fibrosis, and it is important to distinguish it from other fibrotic and granulomatous lung diseases which have different etiologies and treatments.

Silicosis is a common occupational lung disease which results from the inhalation of particles of crystalline silica (2). It has acute, accelerated and chronic forms. Chronic silicosis, which is the most frequently observed form, usually develops after more than 20 years of exposure to relatively

Correspondence: Mehmet KEFELI

Department of Pathology, Ondokuz Mayıs University, Faculty of Medicine, SAMSUN, TURKEY

E-mail: mehmetkefeli@gmail.com Phone: +90 3623121919 
low amounts of silica. Accelerated silicosis, which is rarely seen, develops after 5 to 20 years exposure to particles of crystalline silica. Acute silicosis (silicoproteinosis), also rarely seen, occurs in association with massive exposure to finely particulate silica within a 3 year period. Acute silicosis is histopathologically different to the other two forms. It is characterized by air spaces filling with proteinaceous material, which is a condition similar to idiopathic alveolar proteinosis. Buechner and Ansari coined the term of "silicoproteinosis" for these lesions in 1969 (5). Mixed dust pneumoconiosis (MDP) was defined pathologically by Honma $\mathrm{K}$ et al. as a pneumoconiosis showing dust macules or mixed-dust fibrotic nodules (MDF), with or without silicotic nodules, in an individual with a history of exposure to mixed dust (6). The latter was defined arbitrarily as a mixture of crystalline silica and non-fibrous silicates (6). Generally, exposure to silica is associated with varying amounts of other minerals. Where the silica content of the dust is below 10\%, MDP rather than silicosis may result (4). We report an unusual case of pneumoconiosis in a man who had worked in an antimony mine for 3 years, and present the clinical, radiological and histopathological findings in this rare case.

\section{CASE REPORT}

A 43-year-old man presented with a 6-month history of dyspnea under exertion and non-productive coughing which had progressively worsened over the preceding month. He had never smoked. On physical examination, his vital signs were: BP, 140/90 mm Hg; heart rate, 105 beats/ min; respiratory rate, 24 breaths/min; and temperature 37 ${ }^{\circ} \mathrm{C}$. He was dyspneic but auscultation revealed bilaterally clear lung fields. Other system examinations were normal. Pulmonary function tests revealed a restrictive defect, with an $\mathrm{FEV}_{1}$ of $1.6 \mathrm{~L}$ ( $75 \%$ of predicted), an FVC of $1.8 \mathrm{~L}$ ( $66 \%$ of predicted), and an $\mathrm{FEV}_{1} / \mathrm{FVC}$ of $88 \%$. Chest X-rays revealed diffuse reticulonodular shadowing in the parenchyma of both lungs. A thoracic CT showed interlobular septal thickening bilaterally; nodular opacities, especially in the upper lobe of right lung; and mediastinal lymph nodes. Open-lung biopsy was performed because these clinical and radiological findings did not suggest a specific disease. The biopsy material measured $3 \times 2 \times 1 \mathrm{~cm}$, was gray-brown in color, and of solid appearance. Histological examination revealed many dust-laden macrophages around interlobular septa and pleura, and in peribronchiolar and perivascular areas, associated with some interstitial fibrosis and increased amounts of peribronchiolar and perivascular reticulin fibers (Figure 1). The alveolar spaces were filled with swollen macrophages and amorphous proteinaceous semifluid, the latter being immunoreactive for Human Surfactant Apoprotein A (PE-10, DAKO Japan) (Figure 2). Those swollen macrophages contained cytoplasmic yellowish to black dust particles which represented needleshaped or plate-like, strongly birefringent dust particles together with faintly birefringent small particles under polarized light (Figure 3A,B). There was no stellate shaped fibrosis or well-delineated, acellular fibrotic nodules, like silicotic nodules. Ferruginous bodies were not observed, and neither were specific microorganisms observed with methenamin silver, Ziehl-Neelsen and periodic acid-Schiff (PAS) stains. Immunohistochemically, these macrophages were positive for $\mathrm{CD} 68$, and there were a few S-100 positive cells in lung parenchyma. According to these findings, the case was initially managed as pneumoconiosis. It was subsequently learnt that the patient had worked in an antimony mine for 3 years. Treatment with prednisolon was commenced with an initial dose of $40 \mathrm{mg}$ and the dose was gradually reduced to $10 \mathrm{mg}$ a day over a period of four months.

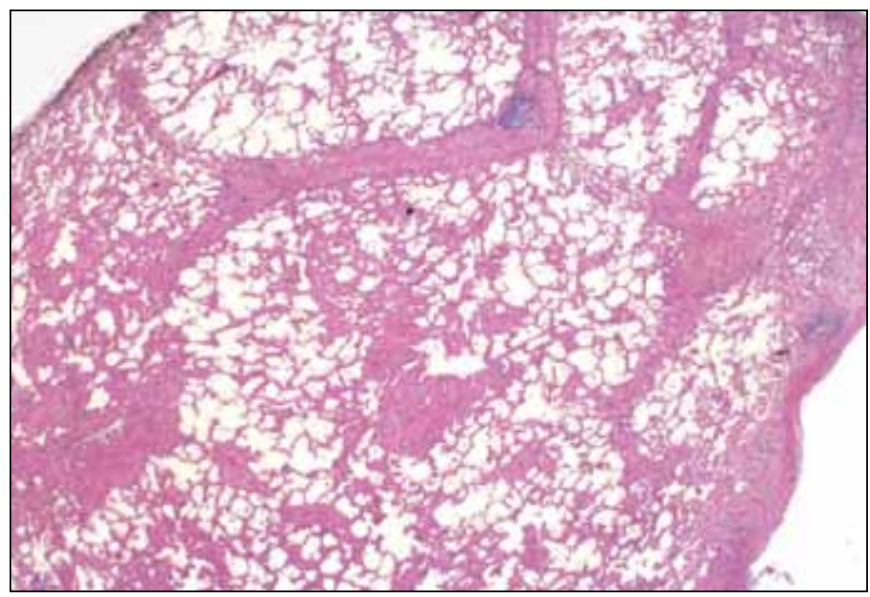

Figure 1: Interstitial fibrosis in lung parenchyma (H\&E, x50).

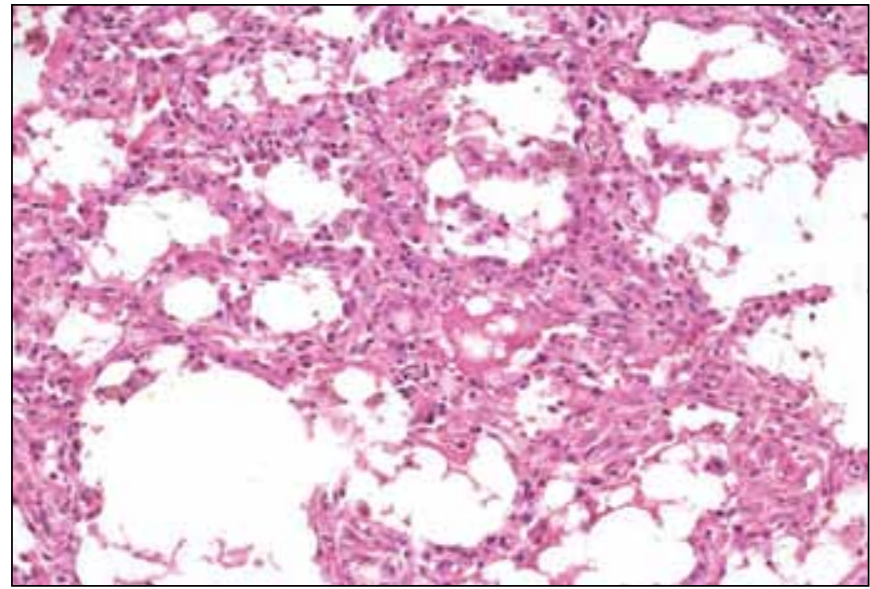

Figure 2: Mild alveolar proteinosis in some alveolar spaces (H\&E, $\mathrm{x} 200)$. 

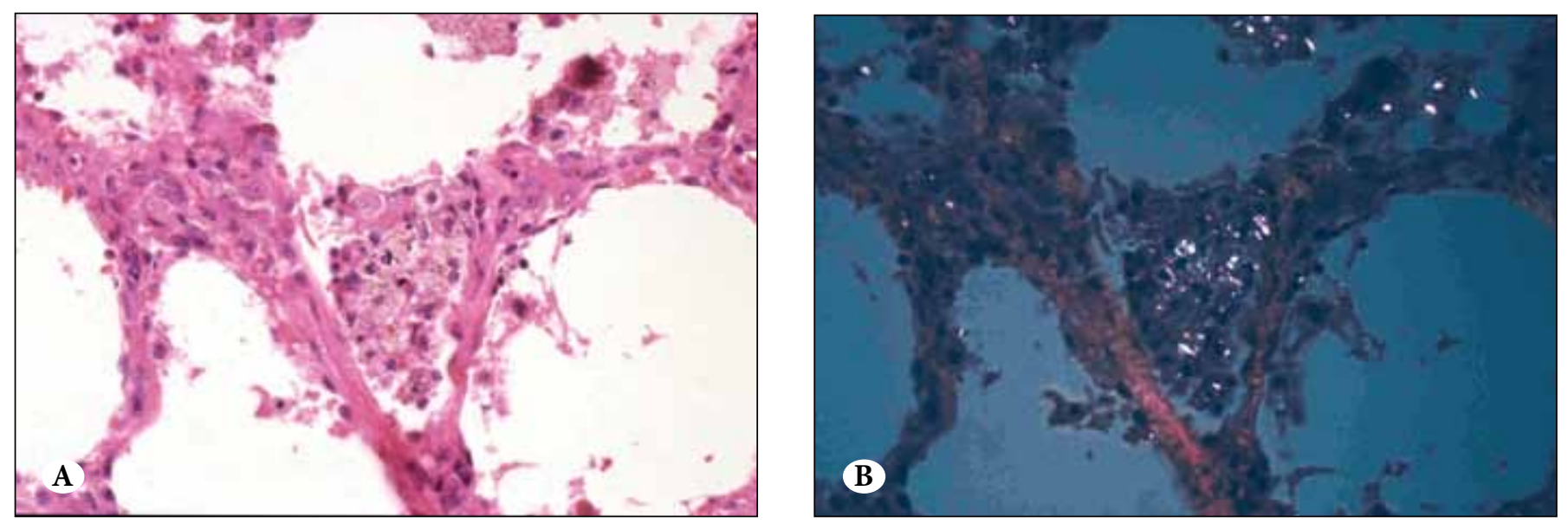

Figure 3: Dust-laden macrophages in alveolar spaces (A: H\&E; x500), engulfing needle-shaped particles and smaller weakly birefringent silica particles under polarized light (B: Polarized light, x500).

To ascertain a final diagnosis, electron microscope analysis of lung tissue was performed. The amount of material available did not allow the performance of tissue digestion and particle quantification (7), so particles were analyzed "in situ" in an unstained histological tissue section mounted on a plastic slide (8). Backscattered electrons were used to detect the particles. This method is particularly sensitive to the detection of metallic particles since the brightness of the signal increases with the mean atomic number of the particle's elemental constituents. This analytical method is however not sensitive to carbonaceous compounds such as soot, coal and diesel particles. The examination was performed at x800 and x1600 magnification. One hundred particles were analyzed and the compounds detected are summarized in Table I. Besides the particle types reported, the presence of carbonaceous compounds can be inferred by the revelation by light microscopy of black particles speckling the dust deposits in the histological sections.

Our diagnosis in this case was acute silicoproteinosis with unusual histopathological findings, rather than MDP, because of the $86 \%$ silica particles found in his mineralogical analysis and also the fact that he had worked in an antimony mine for only 3 years. During the treatment period, slight improvement of pulmonary function and in radiographs was observed. The patient was alive after one year of follow up but was then lost to follow-up.

\section{DISCUSSION}

The prevalence and severity of pneumoconiosis have been decreasing in developed countries in recent decades as a result of regulations limiting worker exposure and early detection of the disease. However, early and accurate differential diagnosis is more important for therapy than for other lung lesions. Many different forms of pneumoconiosis
Table I: Compounds detected by mineralogical analysis of tissue section.

\begin{tabular}{|l|c|}
\hline Minerals & $\begin{array}{c}\text { Distribution } \\
\text { (\%) }\end{array}$ \\
\hline Silica & 86 \\
Mica (Muscovite type) & 5 \\
Antimony compounds (with traces of & 2 \\
iron) & 1 \\
Kaolinite & 1 \\
Albite & 1 \\
Aluminium-Strontium-Phosphorus & 1 \\
compound & 1 \\
Stainless steel (Chromium-Iron-Nickel) & 1 \\
Titanium compound & 1 \\
Tungsten compound & \\
Calcium bearing particle (probably & 1 \\
endogenous) & \\
\hline
\end{tabular}

are known, caused by different dusts, fumes, vapors and gases $(1,2)$. Its reaction and fibrogenicity are related to both the nature of the dust and host response.

Silicosis is an irreversible fibrotic pulmonary disease that may develop after the inhalation of large amounts of silica dust over time. It results from work-related exposure to dusts containing crystalline silica. The disease usually has a long latency period and may present clinically as an acute or chronic disease. The acute form of silicosis (silicoproteinosis) occurs in association with high levels of fine particulate silica. Silicoproteinosis progresses within a few years of initial exposure to rapid failure of respiratory function. Pathological features of acute silicosis 
are characterized by filling of the alveolar spaces with granular, eosinophilic material which is positive to PAS stain. Hyperplasia and metaplasia of type II pneumocytes are evident. Well-developed silicotic nodules are generally absent (2). Marchiori et al. investigated 13 cases of silicoproteinosis. Biopsy was performed in only three cases and revealed intra-alveolar accumulation of proteinaceous material, mild peribronchial granulomatous inflammation and a few silica particles (9). The pathophysiology of chronic silicosis involves chronic inflammation arising from accumulation of various inflammatory mediators and fibrogenic factors (10-12).

Mica is another mineral that can cause pneumoconiosis. It was first implicated as a potential etiological agent for pneumoconiosis by Ferguson in 1932 (13-14). Skullberg et al. reviewed mica-related pneumoconiosis and found 66 cases in the literature. Twenty-six cases of that total suggested purely mica-related pneumoconiosis (14). Histopathologically, the disorder is characterized by dustladen macrophages located around respiratory bronchioles, adjacent alveoli and alveolar ducts. Diffuse interstitial collections of dust-laden macrophages and fibrosis are seen in severe cases (2).

Antimony compounds are widely used in the manufacture of ceramics, glass, paints, pigments, pyrotechnics and fire retardants, and in semiconductor industries (15). Exposure to antimony compounds over long periods, usually the sulfide $\left(\mathrm{SbS}_{3}\right)$ or the oxide $\left(\mathrm{Sb}_{2} \mathrm{O}_{3}\right)$, has occurred in antimony miners and in antimony process workers (16). Potkonjak $\mathrm{V}$ and Pavlovich $M$ investigated the lung function, and clinical and radiological findings of 51 workers in an antimony smelting plant. They found diffuse, densely distributed punctuate opacities in lung parenchyma. Opacities were round or polygonal and usually less than $1 \mathrm{~mm}$ in diameter. They differ from the opacities of silicosis which are usually greater than $3 \mathrm{~mm}$ in size and mainly localized in infraclavicular and mid-lung fields (17). Radiological findings in our patient were bilateral reticular and nodular opacities of different sizes, being most profuse in the upper and middle lung zones.

The term mixed dust pneumoconiosis was first used by Uehlinger in 1946 (6) to describe the lung lesions of ferrous and non-ferrous foundry workers exposed to silica and non-fibrogenic dusts. Honma et al. later defined MDP, based on pathologic descriptions of exposure to mixtures of crystalline silica and non-fibrous silicates. They described three types of lesion: macule, MDF and silicotic nodules.
Macules are interstitial accumulations of dust-laden macrophages. These cells are typically peribronchiolar and perivascular (6). A MDF lesion is irregularly contoured and stellate-shaped, and with collagenization. Silicotic nodules are well-delineated, firm, mostly acellular fibrotic nodules.

In our case, stellate-shaped fibrosis and silicotic nodules were not seen. There were numerous dust-laden macrophages distributed in the alveoli, around the interlobular septa, pleura and respiratory bronchioles. Macrophage aggregations were pronounced. Alveolar spaces were therefore difficult to observe in some areas, where amorphous proteinaceous semifluid was retained, filling the alveolar spaces. There was only minimal interstitial fibrosis. Although some pathologic features were not typical, our diagnosis in this case was acute silicoproteinosis with unusual histopathological findings, rather than MDP, on the basis of our mineralogical analysis and the case's clinical history. To our knowledge, these pathological features are described for the first time in a patient with silicoproteinosis.

The pathologic and radiological findings of pneumoconiosis can resemble those of other fibrotic and granulomatous disorders of the lungs, so its differential diagnosis can be problematic. Analytical electron microscopy provides a powerful tool for the identification of dust in lung tissue samples. The microscope consists of a scanning or transmission electron microscope equipped with an energy dispersive spectrometer. Electron microscopy permits the detection of particles too small to be observed by light microscopy. Energy dispersive X-ray analysis identifies the elemental composition of individual particulates which can be critical to the identification of the source of the inhaled dust (1)

Although our case had some different pathologic features, he was diagnosed with silicoproteinosis, which was inferred to be occupational, based on the occupational history, physical examination, and radiological and electron microscopic findings. The medical and social implications of a correct diagnosis of pneumoconiosis are important. The elimination of other specific diagnoses such as sarcoidosis, tuberculosis, eosinophilic granuloma and usual interstitial pneumonia should prevent unnecessary treatment, since pneumoconiosis has no specific treatment. It should also result in a more accurate determination of prognosis, encourage the patient to stop exposure, and also entitle that person to claim occupational disease compensation available under national laws. 


\section{REFERENCES}

1. Husain AN, Kumar V: The Lung. In Kumar V, Abbas AK, Fausta N. (Eds): Robbins and Cotran Pathologic Basis of Disease. 7th ed., Philadelphia, Elsevier Saunders, 2004, 711-772

2. Gibbs AR: Occupational Lung Disease. In Hasleton PS. (Ed): Spencer's Pathology of the Lung. 5th ed., New York, McGraw Hill, 1996, 461-502

3. Roggli VL, Butnor KJ: Pneumoconioses. In Leslie KO, Wick MR. (Eds): Practical Pulmonary Pathology. Philadelphia, Churchill Livingstone, 2005, 303-333

4. Gibbs AR, Attanoos RL: Environmental and Toxin Induced Lung Diseases. In Zander DS, Farver CF. (Eds): Pulmonary Pathology. China, Churchill Livingstone, 2008, 374-396

5. Buechner HA, Ansari A: Acute silico-proteinosis. A new pathologic variant of acute silicosis in sandblasters, characterized by histologic features resembling alveolar proteinosis. Dis Chest 1969, 55:274-278

6. Honma K, Abraham JL, Chiyotani K, De Vuyst P, Dumortier P, Gibbs AR, Green FH, Hosoda Y, Iwai K, Williams WJ, Kohyama N, Ostiguy G, Roggli VL, Shida H, Taguchi O, Vallyathan V: Proposed criteria for mixed-dust pneumoconiosis: definition, descriptions, and guidelines for pathologic diagnosis and clinical correlation. Hum Pathol 2004, 35:1515-1523

7. Dumortier P, De Vuyst P, Yernault JC: Comparative analysis of inhaled particles contained in human bronchoalveolar lavage fluids, lung parenchyma and lymph nodes. Environ Health Perspect 1994, 5:257-259

8. Abraham JL, Burnett BR, Hunt A: Development and use of a pneumoconiosis database of human pulmonary inorganic particulate burden in over 400 lungs. Scanning Microsc 1991, 5: 95-108
9. Marchiori E, Souza CA, Barbassa TG, Escuissato DL, Gasparetto EL, Souza AS Jr: Silicoproteinosis: high-resolution CT findings in 13 patients. AJR Am J Roentgenol 2007, 189:1402-1406

10. Muetterties M, O'Halloran Schwarz L, Wang R: Sandblasters. In: Greenberg M, (Ed): Occupational, Industrial, and Environmental Toxicology, 2nd ed., Philadelphia, Mosby, 2003

11. Goodwin SS, Stanbury M, Wang ML, Silbergeld E, Parker JE: Previously undetected silicosis in New Jersey decedents. Am J Ind Med 2003, 44:304-311

12. Antao VC, Pinheiro GA, Terra-Filho M, Kavakama J, Müller $N L$ : High-resolution CT in silicosis: correlation with radiographic findings and functional impairment. J Comput Assist Tomogr 2005, 29:350-356

13. Zinman C, Richards GA, Murray J, Phillips JI, Rees DJ, GlynThomas R: Mica dust as a cause of severe pneumoconiosis. Am J Ind Med 2002, 41:139-144

14. Skulberg KR, Gylseth B, Skaug V, Hanoa R: Mica pneumoconiosis-a literature review. Scand J Work Environ Health 1985, 11:65-74

15. Winship KA: Toxicity of antimony and its compounds. Adverse Drug React Acute Poisoning Rev 1987, 6:67-90

16. McCallum RI: Occupational exposure to antimony compounds. J Environ Monit 2005, 7:1245-1250

17. Potkonjak V, Pavlovich M: Antimoniosis: A particular form of pneumoconiosis. I. Etiology, clinical and X-ray findings. Int Arch Occup Environ Health 1983, 51:199-207 